\title{
ZINC STATUS IN ADULTS IN NORTHERN SERBIA
}

\author{
Maša B. Todorović ${ }^{1}$, Velibor S. Čabarkapa ${ }^{\star 1,2}$, Mirjana J. Đerić ${ }^{1,2}$, Jan J. Suđi, ${ }^{3,5}$, \\ Branislava P. Ilinčić ${ }^{1,2}$, Aleksandra D. Trifu', Sofija P. Davidović ${ }^{4}$ \\ ${ }^{1}$ Clinical Center of Vojvodina, Center of Laboratory Medicine, 21000 Novi Sad, \\ Hajduk Veljkova 1-9, Serbia \\ ${ }^{2}$ University of Novi Sad, Faculty of Medicine, Department of Pathophysiology and Laboratory \\ Medicine, 21000 Novi Sad, Hajduk Veljkova 3, Serbia \\ ${ }^{3}$ University of Novi Sad, Faculty of Medicine, Department of Pharmacy, 21000 Novi Sad, Hajduk \\ Veljkova 3, Serbia \\ ${ }^{4}$ Clinical Center of Vojvodina, Clinic of Ophthalmology, 21000 Novi Sad, Hajduk Veljkova 1-9, Serbia \\ ${ }^{5}$ Institute of Occupational Health, 21000 Novi Sad, Futoška 121, Serbia
}

\author{
*Corresponding author: \\ Phone: +38121484 3138 \\ Fax: +38121529148 \\ E-mail: VELIBOR.CABARKAPA@mf.uns.ac.rs
}

ABSTRACT: Zinc plays an essential role in many enzymatic systems, cell division processes, DNA protein synthesis, in immune system functioning, in metabolism regulation of carbohydrates, lipids and proteins: it also has anti-inflammatory and antioxidant effects. There are very few studies which have explored zinc status in general population, so the objective of this study was to examine the zinc status in general adult population in northern Serbia (Province of Vojvodina). 5025 examinees older than 18 years of age have been included in this research (4214 males and 811 females). Anthropometric measurements have been taken from all examinees (body weight and height, body mass index, waist circumference), systolic and diastolic blood pressure; laboratory parameters have been taken by the standard laboratory methods (complete blood count test, total cholesterol, triglycerides, HDL - cholesterol, glucose, creatinine) while the serum concentration od $\mathrm{Zn}$ has been measured by the atomic absorption spectrometry. The results of our study indicate that the presence of low serum zinc concentrations was in $2.28 \%$ of males and $3.82 \%$ of females. The majority of examinees, both males and females, have had the serum zinc concentrations within the reference range (males: $95.02 \%$, females: $94.7 \%$ ). High serum zinc concentration has been present in $2.7 \%$ of examined males and in $1.48 \%$ females. It has been determined, by the analysis of examined parameters, that there is statistically positive correlation between zinc level and the red blood cell count and the hemoglobin level. However, the result of regression analysis showed that low serum zinc concentration had no role in anemia prediction. The results of the study showed that the zinc status in Vojvodina in the majority of males and females is satisfactory, regarding the fact that the low serum zinc concentrations prevalence in male population is $2.28 \%$ and in female population $3.82 \%$.

Key words: essential microelement, screening, nutrition

\section{INTRODUCTION}

Zinc $(\mathrm{Zn})$ in one of the most abundant chemical elements in the Earth's crust and after iron, it is the second most occurred essential microelement in an organism (Lander et al. 2001; Hambridge and Krebs, 2007). It is indispensable in the activities of more than 200 various enzymes and this microelement also plays a significant role in cell division processes, DNK and protein synthesis, and in an immune system functioning (Food and Nutrition Board, 2001). Zinc has anti-inflammatory effect because it leads to a reduction in the level of inflammatory cyto- 
kines (IL6, IL8, TNF-a) (Mariani et al., 2006; Bonaventura et al., 2015). Zinc contributes to the decrease of oxidative stress by taking part in a synthesis of antioxidant enzymes. Zinc, as an enzyme catalyzer, affects carbohydrate, lipid and protein metabolism regulation. This microelement takes part in processes of synthesis, storage and insulin releasing from $\beta$ cells of pancreas so it plays an important role in pathogenesis of diabetes mellitus (Ahn et al., 2014; Otto et al., 2011).

There is $2-3 \mathrm{~g}$ of $\mathrm{Zn}$ in human organism of which approximately $90 \%$ is in muscles and bones, $5 \%$ in liver and skin and the rest is present in prostate, digestive system, heart, kidneys, lungs, in pancreas and brain. Actually, zinc is present in all tissues and predominately it is in fat free mass in intracellular compartment (Maret, 2013). About $80 \%$ of $\mathrm{Zn}$ in a circulation is bound to albumin, while $20 \%$ of $\mathrm{Zn}$ is bound to a2 -macroglobulin (Reyes, 1996). There is $30-40 \%$ of $Z n$ in a cell nucleus, $50 \%$ in a cytosol while the rest of $\mathrm{Zn}$ is a component of cell membrane (Vallee and Falchuk, 1993).

It is difficult to measure $\mathrm{Zn}$ status in adequate way, primarily because of the distribution of this microelement in an organism (Hambrige and Krebs, 2007). The serum concentration is the most common biomarker for $\mathrm{Zn}$ deficiency estimation. However, it is not a reliable indicator of its cell distribution, primarily because of solid homeostatic control mechanisms and because the quantity of $\mathrm{Zn}$ in circulation is approximately $0.1 \%$ of total $\mathrm{Zn}$ amount in a human organism. Zn serum concentration reference values are 11.25-25.9 $\mu \mathrm{mol} / \mathrm{L}$ for males, and 10.7-22.4 $\mu \mathrm{mol} / \mathrm{L}$ for females, measured by atomic absorption spectrometry.

Since a human organism does not possess any $\mathrm{Zn}$ reserves, a regular dietary intake of this microelement is necessary. Zinc is predominately found in food of animal origin and also in seafood, while in less quantity it can be found in whole grains and dairy products. Recommended daily intake for the adults is $11 \mathrm{mg} /$ day for males and $8 \mathrm{mg} /$ day for females (Maret, 2013).
Zinc absorption is performed in duodenum and jejunum and it is regulated by various mechanisms. Hormones and cytokines regulate $\mathrm{Zn}$ status via transporters: $\mathrm{Zn}$ transporters $(Z n T)$ and united proteins (ZIP), Zn-regulated transporter 1 (Zrt1) and ironregulated transporter 1 (Irt1), that enable increase of $\mathrm{Zn}$ absorption and also elimination of $\mathrm{Zn}$ excess (Hess, 2007; Hennigar et al., 2016).

There is not great number of public studies nowadays which examine $\mathrm{Zn}$ status in a human organism and present studies show the results that are not congruent (Olechnowicz, 2018). However, the majority of studies show that the Zn deficiency can be seen in states of higher oxidation stress, inflammatory process, in patients with metabolic syndrome, diabetes mellitus type 2 (DM2) and arterial hypertension (HTA) comparing to healthy population (Seo et al., 2014; Daradkeh et al. 2014; Marcinek et al., 2015).

According to our knowledge, there are no data of $\mathrm{Zn}$ status in Serbia in general population and as well as of association of this microelement with different diseases. That is why the objective of this study was to examine $\mathrm{Zn}$ status in general population of the adults in the region of northern Serbia.

\section{MATERIALS AND METHODS}

This cross-sectional study was carried on in the period started from June 2016 until May 2017 in Institute of Public Health of Vojvodina, in the town of Novi Sad, and encompassed 5025 examinees of general population (4214 men and 811 women) older than 18 years of age from the region of northern Serbia. This study was approved by the ethic committee of Institute of Public Health of Vojvodina and the Declaration of Helsinki principles was respected.

The examinees were informed about the study protocol and they signed the agreement for taking part in the study. Then, the anthropometric parameters were measured (body weight and height, body mass index (BMI) and waist circumference (WC)). The body heights of examinees were measured by Harpenden Anthro- 
pometer (Holtain Ltd, Crowell, UK) of $0.1 \mathrm{~cm}$ accuracy. Body weight was measured in upright position on an electronic scale with an accuracy of $100 \mathrm{~g}$, BMl was calculated as ratio between body weight and by the square of the body height $\left(\mathrm{kg} / \mathrm{m}^{2}\right)$. For measuring WC the Holtain tape was used (Holtain Ltd, Croswell, UK) with the accuracy of $0.1 \mathrm{~cm}$. Waist circumference was measured in the middle between the lowest rib and the highest spot of the hip bone. The blood pressure was measured to all examinees by the Riva Rocci method (Ponte et al., 2013).

Hypertensive patients were considered examinees with diagnosed hypertension and those who are on antihypertensive therapy. Diabetes patients were considered examinees with diagnosed diabetes and those on hypoglycaemic therapy.

All the examinees with acute inflammatory disease and those suffering from malignant diseases were excluded from this study.

The examinees were grouped by the gender and then each, males and females were divided into three groups according to zinc serum level. The men with the low (hypo ZnM), normal - (normo ZnM) and high $\mathrm{Zn}$ concentrations (hyper $\mathrm{ZnM}$ ) and women with low- (hypo ZnF), normal (normo $\mathrm{ZnF}$ ) and high zinc serum concentrations (hyper ZnF).

\section{Laboratory parameters}

Blood samples were collected after 12 hours of fasting and blood sample was analyzed within two hours.

The level of $\mathrm{Zn}$ was determined by atomic absorption spectrometry. (PerkinElmerPinAAcle 900F Atomic Absorption Spectometer, using commercial reagents of the Carl Roth $\mathrm{GmgH}+\mathrm{Co}$.KG, Karishure, Germanu and SERODOS, Wiesbaden, Germany).

The levels of total cholesterol, triglycerides, and HDL- cholesterol in serum were determined by standard biochemical method, on Mindray, biochemical serum analyzer using commercial reagents of the firm Mindray, Shenzhen, China.

Complete blood count was measured by the method of flow cytometry on the hematology counter Horiba $A B X$ using commercial reagents (Horiba, ABX, SAS, Montpellier, France).

\section{Statistical analyses}

Descriptive statistical indicators were used to show the results of the research: arithmetic mean, standard deviation (SD), median, interquartile range. The results are shown as graphics and tables. For the determination of statistically significant difference of examined variables between the groups, ANOVA test, Kruskal-Wallis $\mathrm{H}$ test and as well as adequate post hoc test were used. The Chi-square test was used for categorical data. Pearson coefficient was used for the examination of a possible correlation between certain parameters. Logistic regression analysis was used to explain the relationship between $\mathrm{Zn}$ status as dependent variable and more examined independent variables (glycaemia, age, current smoking, BMI, WC), as well as anemia, DM and HTA as dependent variables and other examined variables as independent variables. The level $p<0.05$ was taken as statistically significant. Statistical data analysis was done by STATISTICA 14.0 statistic software (StatSoft Inc., Tulsa, OK, USA).

\section{RESULTS AND DISCUSSION}

Baseline anthropometric, clinical and laboratory characteristics of male examinees were listed in Table 1 and 2.

Results showed that the lowest percentage of smokers was detected in the group of male examinees with hyperZnM (2.33\%). Hematocrit values and number of red blood cell (RBC) were significantly higher in the HyperZnM examinee group, in reference to the other examined groups, while the serum HDL choresterol concentration levels were significantly lower in the HyperZnM group in reference to the examinee group NormoZnM. Also, the number of monocytes was significantly lower in the group NormoZnM in reference to the group HypoZnM $(p<0.001)$.

Baseline anthropometric, clinical and laboratory characteristics of female examinees were listed in Table 3 and 4. 
Table 1.

Characteristics of male examinees

\begin{tabular}{rccc}
\hline Characteristics & $\begin{array}{c}\text { HypoZnM } \\
(\mathbf{n = 9 6 ; ~ 2 . 2 8 \% )}\end{array}$ & $\begin{array}{c}\text { NormoZnM } \\
(\mathbf{n = 4 0 0 4 ; ~ 9 5 . 0 2 \% )}\end{array}$ & $\begin{array}{c}\text { HyperZnM } \\
(\mathbf{n = 1 1 4 ; ~ 2 . 7 0 \% )})\end{array}$ \\
\hline Age (years) & $44.8 \pm 12.5$ & $43.5 \pm 12.7$ & $41.8 \pm 12.9$ \\
Education (\%) & & & \\
Primary school & 1.77 & 93.9 & 4.30 \\
High school & 2.2 & 95.3 & 2.46 \\
College & 2.1 & 92.5 & 5.35 \\
Faculty & 3.8 & 94.7 & 1.45 \\
Currently smokers (\%) & 2.9 & 94.7 & 2.33 \\
Body mass index (kg /m $\left.{ }^{2}\right)$ & $27.19 \pm 4.20$ & $27.60 \pm 4.26$ & $27.86 \pm 4.30$ \\
Waist circumference $(\mathrm{cm})$ & $93.86 \pm 13.10$ & $95.28 \pm 13.50$ & $96.82 \pm 14.42$ \\
Diabetes mellitus (\%) & 0.6 & 95.0 & 4.45 \\
High blood pressure $(\%)$ & 3.11 & 93.2 & 3.65 \\
\hline
\end{tabular}

HypoZnM - group of the examinees with the low serum zinc concentration level; NormoZnM - group of the examinees with normal serum zinc concentration level; HyperZnM - group of the examinees with high serum zinc concentration level

Table 2.

The laboratory parameters of the male examinees

\begin{tabular}{|c|c|c|c|}
\hline Laboratory parameters & $\begin{array}{c}\text { HypoZnM } \\
(n=96 ; 2.28 \%)\end{array}$ & $\begin{array}{c}\text { NormoZnM } \\
(\mathrm{n}=4004 ; 95.02 \%)\end{array}$ & $\begin{array}{c}\text { HyperZnM } \\
(n=114 ; 2.70 \%)\end{array}$ \\
\hline Zinc $(\mu \mathrm{mol} / \mathrm{L})$ & $10.17 \pm 1.16^{a, b}$ & $17.58 \pm 3.41$ & $28.18 \pm 2.01^{\mathrm{a}}$ \\
\hline $\begin{array}{l}\text { Erytrocyte sedimentation } \\
\text { rate }(\mathrm{mm} / \mathrm{h})\end{array}$ & $5.3 \pm 3.6$ & $5.8 \pm 5.7$ & $5.8 \pm 4.9$ \\
\hline $\begin{array}{l}\text { Sistolic blood pressure } \\
(\mathrm{mmHg})\end{array}$ & $138.6 \pm 18.1$ & $136.6 \pm 19.2$ & $136.4 \pm 20.1$ \\
\hline $\begin{array}{l}\text { Diastolic blood pressure } \\
(\mathrm{mmHg})\end{array}$ & $88.3 \pm 11.1$ & $87.1 \pm 11.8$ & $86.6 \pm 13.1$ \\
\hline Red blood cells $\left(\times 10^{12} / \mathrm{L}\right)$ & $5.05 \pm 0.35^{b}$ & $5.12 \pm 0.38$ & $5.24 \pm 0.36^{a}$ \\
\hline Hemoglobin (g/L) & $153.9 \pm 10.0$ & $152.7 \pm 10.2$ & $154.5 \pm 10.8$ \\
\hline Hematocrit (L/L) & $0.45 \pm 0.05^{\mathrm{b}}$ & $0.45 \pm 0.03$ & $0.46 \pm 0.03^{\mathrm{a}}$ \\
\hline Leukocytes $\left(\times 10^{y} / L\right)$ & $8.10 \pm 2.68$ & $7.43 \pm 2.24$ & $7.70 \pm 2.04$ \\
\hline Lymphocytes $\left(\times 10^{y^{\prime}} / \mathrm{L}\right)$ & $2.49 \pm 0.71$ & $2.44 \pm 1.06$ & $2.59 \pm 0.69^{c}$ \\
\hline Platelets $\left(\times 10^{y} / \mathrm{L}\right)$ & $249.6 \pm 60.6$ & $250.7 \pm 50.1$ & $256.1 \pm 55.4$ \\
\hline Granulocytes $\left(\times 10^{y} / \mathrm{L}\right)$ & $5.24 \pm 2.32$ & $4.65 \pm 1.64$ & $4.74 \pm 1.60$ \\
\hline Monocytes $\left(x 10^{9} / \mathrm{L}\right)$ & $0.37 \pm 0.14^{\mathrm{d}}$ & $0.33 \pm 0.14$ & $0.34 \pm 0.11$ \\
\hline Glucose $(\mathrm{mmol} / \mathrm{L})$ & $6.05 \pm 2.27$ & $5.85 \pm 1.58$ & $5.98 \pm 1.76$ \\
\hline Cholesterol (mmol/L) & $5.77 \pm 1.26$ & $5.59 \pm 1,21$ & $5.42 \pm 0.96$ \\
\hline Tryglicerides (mmol/L) & $1.63(0.82-2.33)$ & $1.39(1.03-2.19)$ & $1.62(1.11-2.32)$ \\
\hline $\begin{array}{l}\text { HDL-cholesterol }(\mathrm{mmol} / \mathrm{L}) \\
\text { LDL-cholesterol (mmol/L) } \\
\text { LDL/HDL-cholesterol/ } \\
\text { Creatinine (umol/l) }\end{array}$ & $\begin{array}{l}1.13 \pm 0.37 \\
3.56 \pm 1.46 \\
3.53 \pm 1.79 \\
89.3 \pm 13.9\end{array}$ & $\begin{array}{l}1.18 \pm 0.31 \\
3.65 \pm 0.93 \\
3.28 \pm 1.10 \\
91.0 \pm 18.7\end{array}$ & $\begin{array}{l}1.00 \pm 0.27^{c} \\
3.58 \pm 0.87 \\
3.89 \pm 1.37 \\
90.8 \pm 13.6\end{array}$ \\
\hline \multicolumn{4}{|c|}{$\begin{array}{l}\text { The results are shown as mean } \pm S D \text { or median (interquartile range) } \\
\text { HypoZnM- group of examinees with low serum zinc concentration level; NormoZnM - group of examinees with } \\
\text { normal serum zinc concentration level; HyperZnM group of examinees with the high serum zinc concentration } \\
\text { level; } \\
\text { a - } p<0.001 \text { in reference to NormoZnM, } b-p<0.001 \text { in reference to HyperZnM, } c-p<0.05 \text { in reference to } \\
\text { NormoZnM, } d-p<0.01 \text { in reference to Normo ZnM }\end{array}$} \\
\hline
\end{tabular}

The results of our study show that the female examinees with serum zinc concentrations above upper limit of reference range were significantly younger comparing to the other groups of examinees.
Also, waist circumference is significantly lower in the HyperZnF examinee group in reference to other groups of examinees. The lowest percentage of women smokers was seen in the hyperZnF group of female 
Table 3.

Characteristics of female examinees

\begin{tabular}{|c|c|c|c|}
\hline Characteristics & $\begin{array}{c}\text { HypoZnF } \\
(n=31 ; 3.82 \%)\end{array}$ & $\begin{array}{c}\text { NormoZnF } \\
(n=768 ; 94.7 \%)\end{array}$ & $\begin{array}{c}\text { HyperZnF } \\
(n=12 ; 1.48 \%)\end{array}$ \\
\hline Age (years) & $38.7 \pm 10.6$ & $42.6 \pm 11.5$ & $32.4 \pm 11.9^{a}$ \\
\hline \multicolumn{4}{|l|}{ Education (\%) } \\
\hline Primary school & 2.5 & 95.6 & 1.72 \\
\hline High school & 3.79 & 94.9 & 1.26 \\
\hline College & 4.47 & 92.5 & 2.98 \\
\hline Faculty & 5.47 & 92.9 & 1.56 \\
\hline Currently smokers (\%) & 4.5 & 94.9 & 0.6 \\
\hline \multirow{2}{*}{$\begin{array}{l}\text { Body mass index }\left(\mathrm{kg} / \mathrm{m}^{2}\right) \\
\text { Waist circumference }(\mathrm{cm})\end{array}$} & $24.06 \pm 5.01$ & $25.07 \pm 4.61$ & $22.95 \pm 3.60$ \\
\hline & $77.28 \pm 12.93$ & $80.72 \pm 12.88$ & $73.66 \pm 6.88^{b}$ \\
\hline Diabetes mellitus (\%) & 7.1 & 92.8 & 0.00 \\
\hline High blood pressure (\%) & 3.0 & 96 & 0.75 \\
\hline
\end{tabular}

HypoZnF - the group of female examinees with low zinc concentration level; NormoZnF - the group of female examinees with normal serum zinc concentration level; HyperZnF - the group of female examinees with high serum zinc concentration level;

$A-p<0.01$ in reference to NormoZnF, $b-p<0.05$ in reference to NormoZnF

Table 4.

The laboratory parameters of the female examinees

\begin{tabular}{|c|c|c|c|}
\hline Laboratory parameters & $\begin{array}{c}\text { HypoZnF } \\
(n=31 ; 3,82 \%)\end{array}$ & $\begin{array}{c}\text { NormoZnF } \\
(n=768 ; 94,7 \%)\end{array}$ & $\begin{array}{c}\text { HyperZnF } \\
(n=12 ; 1,48 \%)\end{array}$ \\
\hline Zinc $(\mu \mathrm{mol} / \mathrm{L})$ & $9.48 \pm 1.20^{\mathrm{c}, \mathrm{d}}$ & $16.38 \pm 3.00$ & $27.01 \pm 1.93^{\mathrm{c}}$ \\
\hline $\begin{array}{l}\text { Erytrocyte sedimentation } \\
\text { rate }(\mathrm{mm} / \mathrm{h})\end{array}$ & $9.5 \pm 5.7$ & $9.4 \pm 6.9$ & $7.4 \pm 4.9$ \\
\hline $\begin{array}{l}\text { Sistolic blood pressure } \\
(\mathrm{mmHg})\end{array}$ & $124.8 \pm 20.0$ & $125.1 \pm 18.8$ & $121.2 \pm 11.9$ \\
\hline $\begin{array}{l}\text { Diastolic blood pressure } \\
(\mathrm{mmHg})\end{array}$ & $80.5 \pm 15.1$ & $80.74 \pm 12.12$ & $76.5 \pm 12.1$ \\
\hline Red blood cells $\left(\times 10^{12} / \mathrm{L}\right)$ & $4.33 \pm 0.42^{\mathrm{a}, \mathrm{e}}$ & $4.59 \pm 0.35$ & $4.71 \pm 0.38$ \\
\hline Hemoglobin (g/L) & $135.8 \pm 11.8$ & $133.7 \pm 11.8$ & $135.8 \pm 10.9$ \\
\hline Hematocrit (L/L) & $0.38 \pm 0.03$ & $0.39 \pm 0.03$ & $0.41 \pm 0.02$ \\
\hline Leukocytes $\left(\times 10^{9} / \mathrm{L}\right)$ & $6.39 \pm 1.77$ & $6.81 \pm 1.91$ & $7.42 \pm 1.86$ \\
\hline Lymphocytes (x109/L) & $2.14 \pm 0.49$ & $2.24 \pm 0.62$ & $2.36 \pm 0.49$ \\
\hline Platelets $\left(\times 10^{9} / \mathrm{L}\right)$ & $269.9 \pm 45.0$ & $275.2 \pm 60.4$ & $295.1 \pm 53.4$ \\
\hline Granulocytes (x109\%/L) & $3.95 \pm 1.44$ & $4.28 \pm 1.60$ & $4.76 \pm 2.08$ \\
\hline Monocytes $\left(\times 10^{9} / \mathrm{L}\right)$ & $0.30 \pm 0.07$ & $0.29 \pm 0.11$ & $0.30 \pm 0.07$ \\
\hline Glucose (mmol/L) & $5.14 \pm 0.53$ & $5.31 \pm 0.84$ & $5.14 \pm 0.63$ \\
\hline Cholesterol (mmol/L) & $5.37 \pm 0.69$ & $5.74 \pm 1.16$ & $5.30 \pm 1.70$ \\
\hline Tryglicerides (mmol/L) & $0.88(0.78-1.60)$ & $1.02(0.77-1.58)$ & $1.51(1.09-1.94)$ \\
\hline HDL-cholesterol (mmol/L) & $1.48 \pm 0.28$ & $1.41 \pm 0.69$ & $1.40 \pm 0.21$ \\
\hline LDL-cholesterol (mmol/L) & $3.35 \pm 0.93$ & $3.85 \pm 0.97$ & $3.21 \pm 1.21$ \\
\hline LDL/HDL-cholesterol & $2.37 \pm 0.96$ & $2.93 \pm 1.02$ & $2.25 \pm 0.49$ \\
\hline Creatinine (umol/l) & $76.0 \pm 10.3$ & $76.1 \pm 13.3$ & $74.4 \pm 5.8$ \\
\hline
\end{tabular}

The results are shown as mean $\pm S D$ or median (interquartile range)

HypoZnF group of female examinees with low serum zinc concentration level; NormoZnF - group of female examinees with normal serum zinc concentration level; HyperZnF group of female examinees with high serum zinc concentration level: a $-p<0.01$ in reference to NormoZnF, $c-p<0.001$ in reference to NormoZnF, $d-p<0.001$ in reference to HyperZnF, e $-p<0.01$ in reference to HyperZnF 
examinees $(0.6 \%)$. The results show also that the number of RBC is significantly lower in the group of female examinees with HypoZnF comparing to the other examined groups.

Distribution of serum zinc concentrations $(\mathrm{Zn})$ in male and female examinees were showed in Figure 1.

It was found, by the distribution analysis of serum zinc concentrations in men and women, that the low zinc abundance was present in $2.28 \%$ of male examinees and in $3.82 \%$ of female examinees.

The greatest number of examinees of both genders had serum zinc abundance within reference range (men: 95.0\%, women: $94.7 \%)$. High serum zinc concentrations were present in $2.7 \%$ of the male examinees and in $1.48 \%$ female examinees.

Number of red blood cells (RBC) in men and women compared to serum zinc levels are shown in Figure 2.

The correlation analysis of the investigated parameters showed a statistically significant positive correlation between the levels of $\mathrm{Zn}$ and the number of RBC $(r=0.31, p<0.05)$, as well as hemoglobin levels $(r=0.39, p<0.05)$.

Multiple regression analysis for the prediction of low serum zinc concentration was shown in Table 5.

The model included years, BMI, the presence of diabetes mellitus, the presence of anemia, the level of glycemia and smoking. It was found that age, BMI, the presence of diabetes mellitus, the presence of anemia, the level of glycemia and smo- king are not significant predicators of low serum zinc concentrations. In addition, the results of regression analysis showed that low serum zinc concentration played no role in prediction of HTA, DM and anemia in the examined sample.

Problems in assessment of zinc status in human organism come out from the fact that serum zinc concentration is only a small part of the total zinc content in a human body. In addition to determining the level of $\mathrm{Zn}$ in the serum, other biomarkers of the $\mathrm{Zn}$ status, such as the determination of $\mathrm{Zn}$ in red blood cells and in the hair have been proposed (Lowe, 2009; Benoist et al., 2007). However, although the serum $\mathrm{Zn}$ concentration does not have to reflect the image of cell $\mathrm{Zn}$, it is today the most commonly used biomarker for estimating the deficit of $\mathrm{Zn}$ in the general population (Maret, 2013).

The results of our study showed that in Vojvodina, that is, in the north region of Serbia, serum zinc values range from 11.13 to $25.97 \mu \mathrm{mol} / \mathrm{L}$ in $95 \%$ of the population, and that the zinc level in males was significantly higher than in females $(17.7 \pm 3.9$ vs. $16.4 \pm 3.5 \mu \mathrm{mol} / \mathrm{L}, p<0.001)$.

Some studies also have shown higher values of serum concentrations in males than in females (Beneš et al., 2015), which can be explained by different diet or different hormone status (Johnson, 1992).

A multi-centric European study has shown that a zinc deficiency is a characteristic of elderly population, in which $30 \%$ of examined elderly population had a zinc deficiency (Marcelini et al., 2006).

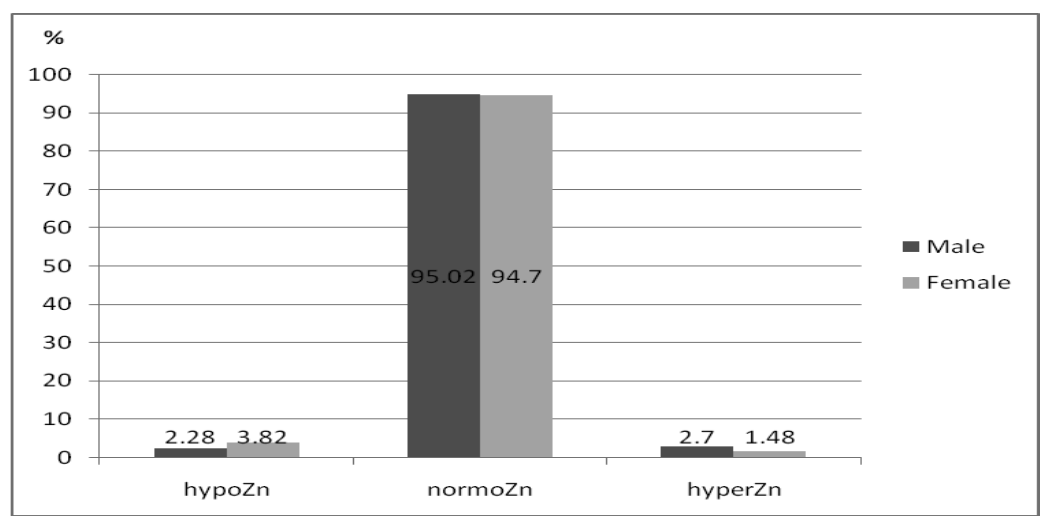

Figure 1 Distribution of serum zinc concentrations $(\mathrm{Zn})$ in male and female examinees 


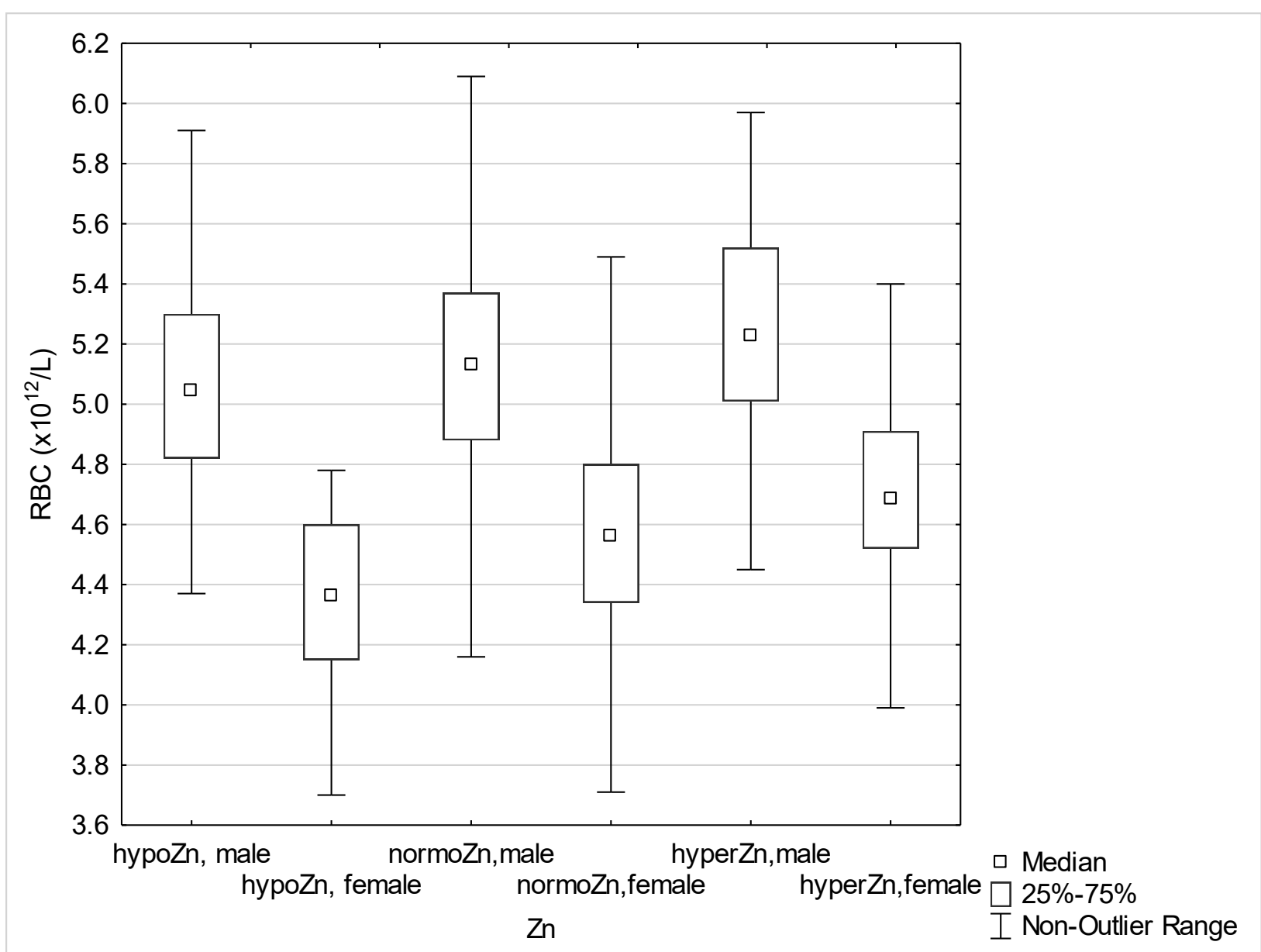

Figure 2. Number of red blood cells (RBC) in men and women compared to serum zinc levels $(p<0.01)$

Table 5.

Multiple regression analysis for the prediction of low serum zinc concentration

\begin{tabular}{lcc}
\hline Predictors & $\mathbf{R}$ & $\mathbf{P}$ \\
\hline Age & $-0,032$ & $\mathrm{p}>0.05$ \\
BMI & 0,028 & $\mathrm{p}>0.05$ \\
DM & 0,053 & $\mathrm{p}>0.05$ \\
Anemia & $-0,055$ & $\mathrm{p}>0.05$ \\
Glycemia & 0,030 & $\mathrm{p}>0.05$ \\
Smoking & $-0,022$ & $\mathrm{p}>0.05$ \\
\hline R-corrolation coefficiont & &
\end{tabular}

$R$ - correlation coefficient

$P$ - probability of the occurrence of the result

The results of our study showed that low serum zinc concentration was found in $2 \%$ of examinees older than 65 years of age. It is considered that the elderly population is at the greatest risk of zinc deficiency, primarily because of low dietary zinc intake but also because of joined comorbidities such as decreased small intestine absorption (Haase, 2009). However, the results of our study does not show a sig- nificant correlation between the zinc level and the examinee age $(p>0.05)$, although the examinees with the serum zinc concentrations above reference range were significantly younger than the other examinees.

Obesity is one of the public health problems and a risk factor for metabolic disorders and numerous chronic diseases (Malekzadeh, 2005). Obese people more fre- 
quently has low serum vitamin and mineral concentrations than people with normal weigh; so low serum zinc concentrations can be found in obese population (Garcia, 2009). Zinc, as an essential micronutrient, plays its role in appetite control and equally in metabolism of macronutrients (Song, 2005). In experiments on animals, it has occurred that intracellular zinc stimulates the pathway of insulin signalization that leads to increased glucose intake, increased lipogenesis and decreased production of free fatty acids (Yoshikawa, 2004). Weight loss, as an approach to the weight control, might lead to the normalization serum values of glucose, insulin and lipids and also to increase of serum zinc concentrations (Jimenez, et al., 1987). Some authors think that in obese people, zinc concentration increases in fatty tissues, so during hypocaloric diet, because of zinc mobilization from a fatty tissue, it comes to secondary increase of serum concentration of this micronutrient (Ryan, 2014).

Numerous studies have indicated the interaction between zinc homeostasis and obesity. Primarily significantly lower serum zinc concentration in obese subjects was indicated, and the low value of $\mathrm{Zn}$ correlated negatively with anthropometric parameters, such as waist circumference and BMl (de Luis et al., 2013; Suliburska et al., 2013; Ferro et al., 2011). However, the results of our study have not indicated statistically significant differences in BMI among male examinees with low, high and normal zinc levels $(27.19 \pm 4.20$ vs. $27.60 \pm 4.26$ vs. $27.86 \pm 4.30 \mu \mathrm{mol} / \mathrm{L}$, $p>0.05)$, neither between examined groups of females with low, high and zinc level within the reference range $(24.06 \pm 5.01$ vs. $25.07 \pm 4.61$ vs. $22.95 \pm 3.60 \mu \mathrm{mol} / \mathrm{L}, \mathrm{p}>0.05)$. Also a statistically significant difference have not been found in waist circumference among males with zinc level under, within and above reference range $(93.86 \pm 13.10$ vs. $95.28 \pm 13.50$ vs. $96.82 \pm 14.42 \mathrm{~cm}, p>0.05$ ). However, there is a statistically significant difference in waist circumference between the group of females with zinc level within the reference range and the group of females with zinc level above the reference range $(80.72 \pm 12.88$ vs. $73.66 \pm 6.88 \mathrm{~cm}$, $\mathrm{p}<0.05)$.

In recent years, studies have been done in order to prove connection between zinc deficiency and developing DM with the premise that zinc deficiency is one of the significant risks for developing of this disease (Sinha, and Sen 2014; Goswami, 2013; Basaki, 2012, Jansen et al., 2012). It has been shown that zinc plays a significant role in the processes of synthesis, storage and secretion of $\beta$ cells of pancreas as response to glucose dietary intake; so a decrease of serum concentrations of this microelement might lead to decrease of cell ability of pancreas to produce and secret insulin and to developing of insulin resistance as well as insulin intolerance (Yanga et al., 2015; de Carvalho et al., 2017). Also, zinc stimulates glycolysis, inhibits gluconeogenesis and has a significant role in glucose transport process. The study of Dasarathan and cooperators (Dasarathan, 2017) has proved that there are lower values of serum zinc concentrations in the group suffering from DM in reference to control group, which is also in accordance with the results of $\mathrm{McNir}$ and cooperators, where inverse association of serum zinc concentration and glycemic status have been seen (McNir et al., 1981).

However, the results of our study indicated that there was no statistically significant difference in zinc values with the males suffering from diabetes compared to heaIthy male examinees (17.88 vs 17.72 $\mu \mathrm{mol} / \mathrm{L}, \quad \mathrm{p}>0.05$ ), while low serum zinc concentrations were detected in healthy population of female examinees compared to those suffering from DM $(16.41 \mu \mathrm{mol} / \mathrm{L}$ vs $17.87 \mu \mathrm{mol} / \mathrm{L}, \mathrm{p}<0.05)$. Similarly to the results of our study, in the Khanrin and coworkers study, no difference was observed in serum zinc concentration in healthy examinees and those suffering from DM which can be explained by the fact the serum zinc concentrations vary under different hormone and metabolic influence (Ekemkcioglu et al., 2001). Also, in our study, the number of examinees suffering from DM was significantly lower comparing to the number of examinees not suffering from DM which can easily 
influence the validity of the obtained results.

The results of our study showed that there was a statistically significant correlation between $\mathrm{Zn}$ and RBC count ( $\mathrm{R}=0.31$, $p<0.05)$ and hemoglobin level $(R=0.39$, $p<0.05)$ as well. However, the results of the study by Pedraze and coauthors were not compatible with the results of our study, because they did not show statistically significant correlation between $\mathrm{Zn}$ and erythrocyte count (Pedraza, 2016), while the Osawe and coauthors study indicated positive correlation between $\mathrm{Hgb}$ and Zn (Osawa, 2002). Micronutrient deficiency and nutritive anemia are significant health problems especially in vulnerable groups of the population such as children, adolescents and pregnant women where there is a higher need for microelements (Jong Weon, 2005). In most cases, zinc deficiency is united with iron deficiency, keeping in mind that $\mathrm{Zn}$ plays a significant role as a cofactor of enzymes which are included in iron metabolism (Ishraga et al., 2009). Primarily, zinc plays a significant role in the enzyme activities of alpha-aminolevulinic acid dehydratase which functions as a main growth regulator of erythrocyte group of cells by modulation of gene expression, specific for erythrocyte group of cells; then zinc stimulates proliferation of immature erythroblasts and provides normal erythropoiesis (World Health Organization Nutrition, 2000).

In this research, we have found that in the group HypoZnM were $2.9 \%$ of smokers, while in the group HypoZnF were $4.5 \%$ of smokers. The lowest percent of smokers were found in the group hyperZnM and hyperZnF (in examined males $2.33 \%$, in examined females $0.6 \%$ ). The results of our study are in accordance to the results of Benes and coauthors study (Benes, 2005). However, the study of Lopes and coauthors (Lopes, 2004) indicates higher zinc values in male smokers which are contrary to the results of our study. The influence of smoking to serum zinc concentrations has not been quite examined yet and the results of studies are contradictive (Szyszko, 2006). There is evidence that zinc can have an effect on the stimulation of nicotinic receptors as well as the effect of cadmium from cigarettes on the metabolism of $\mathrm{Zn}$.

\section{CONCLUSIONS}

The results of the study indicated that zinc status in Vojvodina in most men and women is satisfactory, because a prevalence of low serum zinc concentration in male population is $2.28 \%$ and in female population $3.82 \%$. The results also show that examined parameters (glycemia, age, smoking, BMI, waist circumference, DM, HTA and anemia) are not predictors of decreased serum zinc concentration and also that low serum zinc concentration does not play any role in HTA, DM and anemia prediction (although there is a significant positive correlation between zinc level and hemoglobin and zinc level and RBC count).

\section{ACKNOWLEDGMENTS}

This work was supported by the Provincial Secretariat for Science and Technological Development, Autonomous Province of Vojvodina, Republic of Serbia under grant No 114-451-2013/2016-01 approved.

\section{REFERENCES:}

1. Lander, E.S., Linton, L.M., Birren, B., Nusbaum, C., Zody, M.C., Baldwin, J., et al. (2001). Initial sequencing and analysis of the human genome. Nature, 409, 860-921.

2. Hambidge, K.M., Krebs, N.F. (2007). Zinc deficiency: a special challenge. The Journal of Nutrition, 137, 1101-5.

3. Food and Nutrition Board (2001). Dietary Reference Intakes for Vitamin A, Vitamin K, Arsenic, Boron, Chromium, Copper, Iodine, Iron, Manganese, Molybdenum, Nickel, Silicon, Vanadium, and Zinc, National Academy Press, Washington

4. Mariani, E., Cattini, L., Neri, S., Malavolta, M., Mocchegiani, E., Ravaglia, G, Facchini A. (2006). Simultaneous evaluation of circulating chemokine and cytokine profiles in elderly subjects by multiplex technology: relationship with zinc status. Biogerontology, 7, 449-459.

5. Bonaventura, P., Benedetti, G; Albarède, F., Miossec P. (2015). Zinc and its role in immunity and inflammation. Autoimmunity Reviews, 14 (4), 277-285.

6. Ahn, B.I., Kim, M.J., Koo, H.S., Seo, N., Joo, N. S., Kim, Y.S. (2014). Serum zinc concentration is inversely associated with insulin resistance but not related with metabolic syndrome in nondiabetic Korean adults. Biological Trace Element Research, 160 (2), 169-175. 
7. Otto, M.C.C.D., Alonso, A., Lee, D.H., Delclos, G.L., Jenny, N.S., Jiang, R., Lima, J.A., Symanski, E., Jacobs D.R., Jr, Nettleton J.A, (2011). Dietary micronutrient intakes are associated with markers of inflammation but not with markers of subclinical atherosclerosis. The Journal of Nutrition, 141 (8), 1508S-15S.

8. Maret, W. (2013). Zinc biochemistry: From a single zinc enzyme to a key element of life. Advances in Nutrition, 4 (1), 82-91.

9. Reyes, J.G. (1996). Zinc transport in mammalian cells. American Journal of Physiology, Cell Physiology, 270, 401-410.

10. Vallee, B.L., Falchuk, K.H. (1993). The biochemical basis of zinc physiology. Physiological Reviews, 73, 79-118.

11. Hambidge, K.M., Krebs, N.F. (2007). Zinc deficiency: a special challenge. The Journal of Nutrition, 137, 1101-1105.

12. Hess, S., Peerson, J., King, J., Brown, K. (2007). Use of serum concentration as an indicator of population zinc status. Food and $\mathrm{Nu}$ trition Bulletin, 28, 403-429.

13. Hennigar, S.R., Kelley, A.M., McClung J.P. (2016). Metallothionein and zinc transporter expression in circulating human blood cells as biomarkers of zinc status: a systematic review. Advances in Nutrition, 7 (4), 735-746.

14. Olechnowicz, J., Tinkov, A., Skalny, A., Suliburska, J. (2018). Zinc status is associated with inflamation, oxidative stress, lipid and glucose metabolism. The Journal of Physiological Sciences, 68, 19-31.

15. Seo, J.A, Song, S.W, Han, K., Lee, K.J., Kim, H.N. (2014). The associations between serum zinc levels and metabolic syndrome in the Korean population: findings from the 2010 Korean National Health and Nutrition Examination Survey. PLOS One, 9 (8), e105990.

16. Daradkeh, G., Zerie, M., Othman, M., Chandra, P., Jaiosi, A., Mahmood, L., Alowainati B., Mohammad I., Daghash M. (2014). Zinc status among type (2) diabetes mellitus in the State of Qatar. Public Health Front, 3 (1), 4-10.

17. Marcinek, K., Suliburska, J., Krejpcio, Z., Bogdanski, P. (2015). Evaluation of mineral status in hypertensive patients undergoing pharmacotherapy. Roczniki Państwowego Zakładu Higieny, 66 (1), 61-67.

18. Ponte, B., Pruijm, M., Marques-Vidal, P., Pierre-Yves, M., Burnier, M., Paccaud, F., Gérard Waeber, G., Vollenweider, P., Bochud, M. (2013). Determinants and burden of chronic kidney disease in the population-based CoLaus study: a cross-sectional analysis. Nephrology Dialysis Transplantation, 28, 2329-2339.

19. Lowe, N.M., Fekete, K., Decsi, T. (2009). Methods of assessment of zinc status in humans: a systematic review. The American Journal of Clinical Nutrition, 89, 2040S-51S.

20. de Benoist, B., Darnton-Hill, I., Davidsson, L., Fontaine, O., Hotz, C. (2007). Conclusions of the Joint WHO/UNICEF/IAEA/IZiNCG Interagency meeting on zinc status indicators. British Nutrition Foundation, 28, S480-484.
21. Beneš, B., Spěváčková, V., Šmíd, J., Batáriová, A., Čejchanová, M., Zítková, L. (2015). Effects of age, bmi, smoking and contraception on levels of $\mathrm{Cu}$, Se and $\mathrm{Zn}$ in the blood of the population in the Czech Republic trace element status (Se, Cu, $\mathrm{Zn}$ ) in healthy Portuguese subjects of Lisbon population. Central European Journal of Public Health, 13 (4), 202-207.

22. Johnson, P.E., Milne, D.B., Lykken, G.I. (1992). Effects of age and sex on copper absorption, biological half-life, and status in humans. The American Journal of Clinical Nutrition, 56, 917925.

23. Marcellini, F., Giuli, C., Papa, R., Gagliardi, C., Dedoussis, G., Herbein, G., et al. (2006). Zinc status, psychological and nutritional asessment in old people recruited in five European coutries: Zincage study. Biogerontology, 7, 339-345.

24. Haase, H., Rink, L. (2009). The immune system and the impact of zinc during aging. Immunity and Ageing, 6, 9.

25. Malekzadeh, R., Mohamadnejad, M., Merat, Sh., Pourshams, A., Etemadi, A. (2005). Obesity Pandemic: an Iranian perspective. Archives of Iranian Medicine, 8 (1), 1-7.

26. Garcia, O.P., Long, K.Z., Rosado, J.L. (2009). Impact of micronutrient deficiencies on obesity. Nutrition Research Reviews, 67 (10), 559-572.

27. Song, Y., Wang, J., Li, X.K., Cai, L. (2005). Zinc and the diabetic heart. Biometals, 18 (4), 325-332.

28. Yoshikawa, Y., Ueda, E., Kojima, Y., Sakurai, $\mathrm{H}$. (2004). The action mechanism of zinc (II) complexes with insulinomimetic activity in rat adipocytes. Life Science, 75, 741-751.

29. Jimenez, J., Zuniga-Guajardo, S., Zinman, B., Angel, A (1987). Effects of weight loss in massive obesity on insulin and c-peptide dynamics: Sequential changes in insulin production, clearance, and sensitivity. International journal of Clinical Endocrinology and Metabolism, 64 (4), 661-668.

30. Wessells, R.K, King J.C., Brown, K.H. (2014). Development of a plasma zinc concentration cutoff to identify individuals with severe zinc deficiency based on results from adults undergoing experimental severe dietary zinc restriction and individuals with acrodermatitis enteropathica. The Journal of Nutrition, 144 (8), 1204-1210.

31. de Luis, D.A., Pacheco, D., Izaola, O., Terroba, M.C., Cuellar, L., Cabezas, G. (2013). Micronutrient status in morbidly obese women before bariatric surgery. Surgery for Obesity and Related Diseases, 9 (2), 323-327.

32. Suliburska, J., Cofta, S., Gajewska, E., Kalmus, G., Sobieska, M., Samborski, W., Krejpcio, Z., Drzymala-Czyz, S., Bogdanski, P. (2013). The evaluation of selected serum mineral concentrations and their association with insulin resistance in obese adolescents. European $\mathrm{Re}$ view for Medical and Pharmacological Sciences, 17 (17), 2396-2400.

33. Ferro, F.E.D., de Sousa Lima, V.B., Mello Soares, N.R., Franciscato Cozzolino, S.M., Nascimento Marreiro, D.D. (2011). Biomarkers 
of metabolic syndrome and its relationship with the zinc nutritional status in obese women. Nutrición Hospitalaria, 26 (3), 650-654.

34. Sinha, S., Sen, S. (2014). Status of zinc and magnesium levels in type 2 diabetes mellitus and its relationship with glycemic status. International Journal of Diabetes in Developing Countries, 34 (4), 220-223.

35. Goswami, R.K. (2013). Evaluation of serum zinc status and glycated hemoglobin of type 2 diabetes mellitus patients in a tertiary care hospital of Assam. Journal of Laboratory Physicians, 5, 30-33.

36. Basaki, M., Saeb, M., Nazifi, S., Shamsaei, H. A. (2012). Zinc, copper, iron, and chromium concentrations in young patients with type 2 diabetes mellitus. Biological Trace Element Research, 148, 61-64.

37. Jansen, J., Rosenkranz, E., Overbeck, S., Warmuth, S., Mocchegiani, E., Giacconi, R., Weiskirchen, R., Karges, W., Rink, L. (2012). Disturbed zinc homeostasis in diabetic patients by in vitro and in vivo analysis of insulinmimetic activity of zinc. The Journal of Nutritional Biochemistry, 23, 1458-1466.

38. Yanga, H.K., Leea, S.H., Hanc, K., Kanga, B., Leed, S.Y., Yoona, K.H., Kwona, H.S., Parkf, Y.M. (2015). Lower serum zinc levels are associated with unhealthy metabolic status in normal-weight adults: the 2010 Korea National Health and Nutrition Examination Survey. Diabetes and Metabolism, 41, 282-90.

39. de Carvalho, G.B., Brandão-Lima, P.N., Maia, C.S., Barbosa, K.B.F., Pires, L.V. (2017). Zinc's role in the glycemic control of patients with type 2 diabetes: a systematic review. Biometals, 30 (2), 151-162.

40. Dasarathan, R., Kumar, S., Ganesh, V., Chenthil, K.S. (2017). Study of serum Zinc status among type 2 diabetes mellitus patients. IJAM, 4 (5), 1344-1347.

41. McNair, P., Kiilerich, S., Christiansen, C., Christensen, M.S., Madsbad, S., Transbol, I. (1981). Hyperzincuria in insulin treated diabetes mellitus-its relation to glucose homeostasis and insulin administration. Clinica Chimica Acta, 112 (3), 343-348.

42. Ekmekcioglu, C., Prohaska, C., Pomazal, K., Steffan, I., Schernthaner, G., Marktl, W. (2001).
Concentrations of seven trace elements in different hematological matrices in with type 2 diabetes as compared to healthy controls. Biological Trace Element Research, 79, 205219.

43. Pedraza, D.F., Rocha, A.C. (2016). Micronutrient deficiencies in Brazilian children attending daycare centers: a review of the literature. Ciência and Saúde Coletiva, 21, (5) 15251544.

44. Osawa, M., Yamaguchi, T., Nakamura, Y., Kaneko, S., Onodera, M., Sawada, K., Jegalian, A., Wu, H., Nakauchi, H., Iwama, A. (2002). Erythroid expansion mediated by the Gfi-1B zinc finger protein: role in normal hematopoiesis. Blood, 100 (8), 2769-2777.

45. Jong Weon, C., Soon Ki, K. (2005). Relationships of lead, copper, zinc, and cadmium levels versus hematopoiesis and iron parameters in healthy adolescents. Annals of Clinical and Laboratory Science, 35, 4.

46. Ishraga, A., Hyder, M., Ayoub, M., Naji, A., Mustafa, E., Adam, I. (2009). Anaemia, folate, zinc and copper deficiencies among adolescent schoolgirls in eastern Sudan. Biological Trace Element Research, 132, 60-66.

47. WHO (2000). WHO Nutrient Profile for SouthEast Asia Region, WHO Regional Office for South-East Asia, New Delhi. (http://www.who.int/iris/handle/10665/253459).

48. Benes, B., Spevácková, V., Smíd, J., Batáriová, A., Cejchanová, M., Zítková, L. (2005). Effects of age, BMI, smoking and contraception on levels of $\mathrm{Cu}$, Se and $\mathrm{Zn}$ in the blood of the population in the Czech Republic. Central European Journal of Public Health, 13 (4), 202207.

49. Lopes, P.A., Santos, M.C., Vicente, L., Rodrigues, M.O., Pavăo, M.L., Neve, J., Viegas-Crespo, A.M. (2004). Trace element status (Se, Cu, Zn) in healthy Portuguese subjects of Lisbon population. Biological Trace Element Research, 101 (1), 1-17.

50. Szyszko, M., Czarnowski, W. (2006). Smoking influence on cadmium, lead selenium and zinc level in placenta, cord blood and maternal blood of women at delivery from Gdansk region. Przegląd Lekarski, 63, 993-997. 


\section{СТАТУС ЦИНКА У ПОПУЛАЦИЈИ ОДРАСЛИХ У СЕВЕРНОЈ СРБИЈИ}

Маша Б. Тодоровић ${ }^{1}$, Велибор С. Чабаркапа ${ }^{{ }^{1,2}}$, Мирјана Ј. Ђерић $\hbar^{1,2}$, Јан Ј. Суђи ${ }^{3,5}$, Бранислава П. Илинчић ${ }^{1,2}$, Александра Д. Трифуу ${ }^{1}$, Софија П. Давидовић ${ }^{4}$

${ }^{1}$ Клинички Центар Војводине, Центар за лабораторијску медицину, 21000 Нови Сад, Хајдук Вељкова 1-9, Србија

${ }^{2}$ Универзитет у Новом Саду, Медицински фракултет, Департман за патолошку физиологију и лабораторијску медицину, 21000 Нови Сад, Хајдук Вељкова 3, Србија

${ }^{3}$ Универзитет у Новом Саду, Медицински фракултет, Департман за фрармацију, 21000 Нови Сад, Хајдук Вељкова 3, Србија

${ }^{4}$ Клинички центар Војводине, Офтталмолошка клиника, 21000 Нови Сад, Хајдук Вељкова 1-9, Србија

${ }^{5}$ Институт за јавно здравље, 21000 Нови Сад, Футошка 121, Србија

Сажетак: Цинк има значајну улогу у многим ензимским системима, у процесима ћелијске деобе, синтезе ДНК и протеина, у фрункционисању имунског система, у регулацији метаболизма угљених хидрата, липида и протеина, а осим тога има и антиинфраматорно и антиоксидансно дејство. Врло је мало студија које су испитивале статус цинка у општој популацији, те је и циљ ове студије био да испита статус цинка у општој популацији одраслог становништва у региону северне Србије (Војводина). У студију је укључено 5025 испитаника (4214 мушкарац и 811 жена) старијих од 18 година. Свим испитаницима одређивани су антропометријски параметри (телесна тежина и висина, индекс телесне масе, обим струка), систолни и дијастолни крвни притисак, стандардним лабораторијским методама лабораторијски параметри (комплетна крвна слика, укупни холестерол, триглицериди, ХДЛхолестерол, глукоза, креатинин), док је серумска концентрација цинка одређивана атомском апсорпционом спектрометријом. Резултати наше студије показују да је заступљеност ниске вредности цинка у испитивној групи мушкараца износила $2,28 \%$, док је ниска вредност цинка била присутна код $3,82 \%$ женских испитаница. Највећи број испитаника оба пола имало је серумске концентрације цинка у границама референтног опсега (мушкарци: 95.2\%, жене: $94.7 \%)$. Повишена серумска концентрација цинка је била присутна у 2,7\% испитиваних мушкараца и у $1,48 \%$ испитиваних жена. Анализом испитиваних параметара утврђена је статистички значајна позитивна корелација између нивоа цинка и броја еритроцита и хемоглобина. Међутим резултати регресионе анализе указују да снижена серумска концентрација цинка нема улогу у предикцији анемије. Резултати студије указују да је статус цинка у Војводини код већине мушкараца и жена задовољавајући, с обзиром на то да преваленција ниских серумских концентрација цинка у мушкој популацији износи 2,28\%, односно у женској $3,82 \%$.

Кључне речи: есенцијални микроелемент, скрининг, исхрана

Received: 7 December 2018

Received in revised form: 14 January 2019

Accepted: 14 February 2019 